\title{
Relation between boundaries of protected areas and the distribution of vulnerable natural habitats - a case study from Sharri National Park, SE Europe
}

\author{
Naim Berisha ${ }^{1,2, *}$, Renata Ćušterevska ${ }^{2}$, Kimete Lluga-Rizani ${ }^{1}$, \\ Fadil Millaku', Vlado Matevski ${ }^{2,3}$ \\ ${ }^{1}$ Faculty of Mathematics and Natural Sciences, University of Prishtina, St. “George Bush”, no. 31, 10000 , \\ Prishtina, Kosovo \\ ${ }^{2}$ Institute of Biology, Faculty of Natural Sciences and Mathematics, Ss. Cyril and Methodius University, Str. \\ "Arhimedova" no. 3, 1000, Skopje, North Macedonia \\ ${ }^{3}$ The Macedonian Academy of Sciences and Arts, Bul. "Krste Misirkov", no. 2, 1000, Skopje, North Macedonia \\ *corresponding author' e-mail: naim.berisha@uni-pr.edu
}

Received: 26 February 2020 / Accepted: 4 September 2020

\begin{abstract}
A growing threat to areas designed to protect habitats with high biodiversity has been noticed. In order to assess the present level of threat, the correlation between the factual situation of natural habitats and the boundary of protected area was studied in the massif of Luboten, Sharri NP. 45 phytosociological relevès were made in the studied site, all habitat types were recorded and notes on presence of rare and endemic plant taxa were taken. It was noticed that within the massif of Luboten, Sharri NP, an endangered natural habitat of subalpine moist tall herbs is not covered within the strictly protected area. The Moesian hogweed tall herb communities with Cirsium appendiculatum Griseb., as the most distinctive plant species, are known to harbor several endemic and rare plant species. To further add conservation importance, in these habitats with narrow distribution and fragile environment, there is one South-European Orophilous plant species (Willemetia stipitata), as well as 12 Balkan endemic plant taxa. The corresponding recorded plant association is Doronico gigantei-Cirsietum appendiculati Horv. ex Quez. Based on the obtained data on the situation of this habitat, we highly suggest extending the strictly protected area for $0.56 \mathrm{~km}^{2}$ into the NW direction of the western slope.
\end{abstract}

Keywords: EUNIS, habitat disturbance, Kosovo, nature conservation, phytosociology, diversity.

\section{Introduction}

The role and function of protected areas is of critical importance to our understanding, since it is directly related to the efficiency of conserving biodiversity as well as sustaining the local livelihoods. One of the utmost biodiversity conservation promotions from The World Conservation Union (IUCN) is the establishment of the protected areas. They are defined as "a clearly defined geographical space, recognized, dedicated and managed through legal or other effective means to achieve the long-term conservation of nature with associated ecosystem services and cultural values" (Dudley, 2008). As of 2007 IUCN estimates that are 
more than 100.000 protected areas worldwide that fall into one of six categories of conservation, extending from strictly protected areas where human activity is limited to those that permit sustainable human use (IUCN, 2007).

Numerous protected areas that belong to the developing countries are characterized with a unique developmental pattern, which is related to the local people dependency on natural resources for their very existence (Wilshusen et al., 2003). Anyhow, this complex matrix of dependency and development that encompasses grasslands, agriculture, forests as well as varying unprotected sites is characterized with many surrounding pressures (Terborgh \& van Schaik, 2002) towards natural resources that may either continuously or intermittently challenge conservation of protected areas. Due to these pressures and the dependency matrixes and known complex processes that entail natural habitats and resources, protected areas represent an important strategy towards protecting and conserving natural habitats (Brown et al., 2009).

Anyhow, so far there have been only few assessments of the ecological effectiveness of protected areas (Gaston et al., 2006) despite of their widespread popularity. Those few studies that have attempted to assess of protected areas towards preserving environment against degradation, include interview based qualitative assessments (Barber et al., 2012), assessments on the degree of forest cover change from one time period to another (DeFries et al., 2005), and change in abundance for certain target taxa and their potential threats (Tuya et al., 2006) among few other studies. From many studies made so far (Rowell, 1993; Jones, 2000; Hockings, 2003) in regard to the strategies used by implementing organizations that additionally assess the effectiveness of protected areas management, it can be concluded that it represents a complex interconnectivity of different dynamic subfields in order to achieve a practical and useful management of protected areas.

If the objective of protection zones within the National Park is to conserve biodiversity, then we need to make sure that the boundaries of strictly protected area are properly set in order to reach real protection goals.

Functional and taxonomic diversity as components of biodiversity generally concern the range of roles that organisms play on their communities and ecosystems. Either though the concept of functional diversity itself remains largely complex and many definitions for it exist (Bengtsson, 1998; Diaz \& Cabido, 2001), a more specific definition was offered by Tilman (2001) defining it as "the value and range of certain species and organismal traits that influence ecosystem functioning". 
These chosen variables are believed to serve as effective representatives for ecological effectiveness of protected areas and they are not easily measured with frequently used monitoring tools such as satellite imagery. It is well known that biodiversity plays a crucial role in regulating ecosystem processes and functions, while it conveys much information about the extent and degree of environmental changes within a given system (Tilman, 1999; Chapin et al., 2000; Hooper et al., 2005). Additionally, taxonomic diversity has been the primary form for measuring the biodiversity. Recently, functional diversity - which measures the range of roles that organisms play in a community - has gained increasing prominence for assessing species diversity (Petchey \& Gaston, 2002, 2006).

Our study aims were to: $a$ ) identify key plant communities within and outside the strictly protected area, $b$ ) conduct a comparative functional and taxonomic diversity assessment between those communities, $c$ ) evaluate the presence of rare and endangered plant taxa within these plant communities, $d$ ) verify the boundaries of strictly protected areas and their compliance with the extent of certain, fragile plant communities and $e$ ) presence and quality of certain natural habitats and the interrelation between same habitats under different pressure conditions on site. 


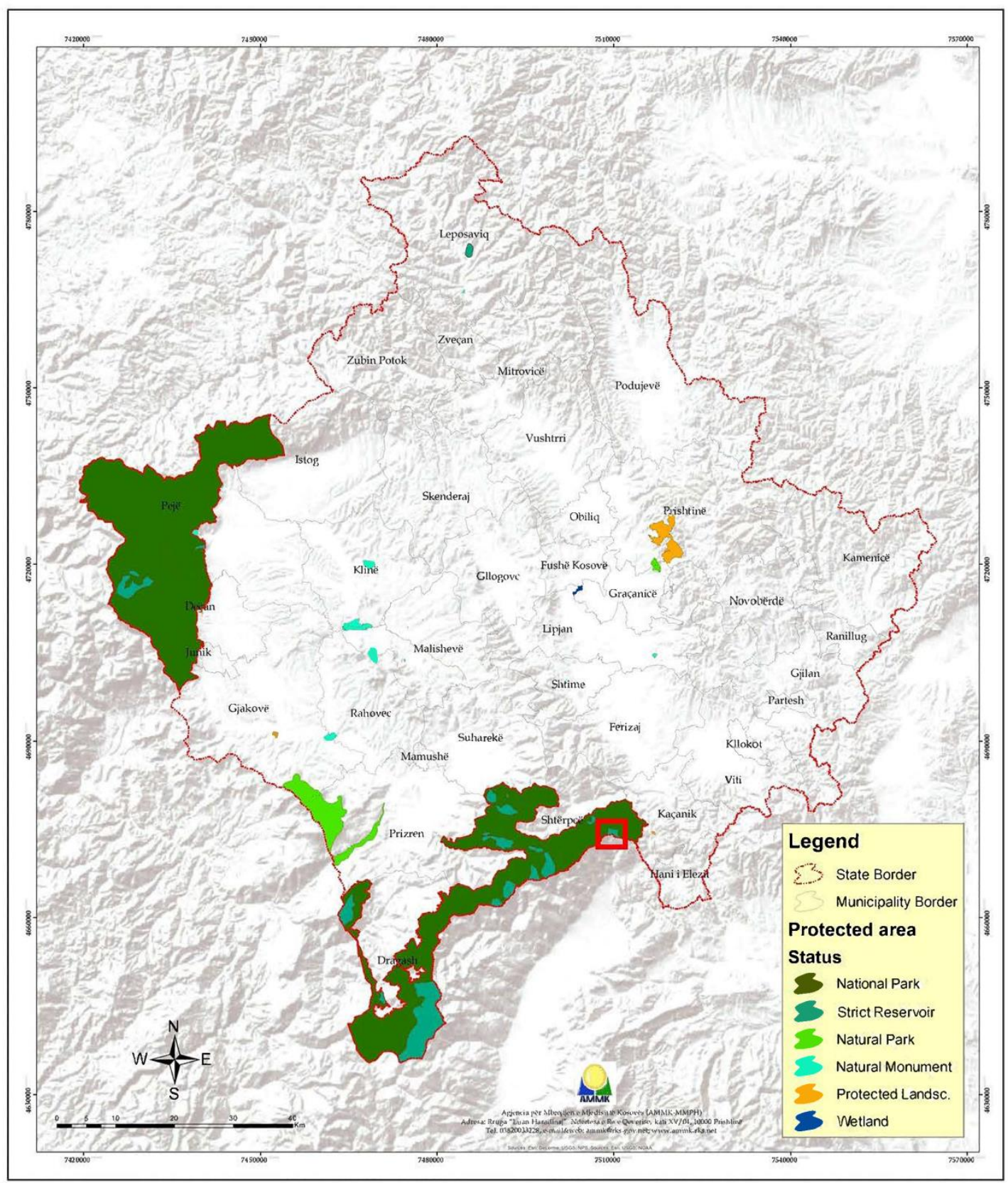

Figure 1. Map of protected areas in Kosovo. Red square indicates the position of the Mt. Luboten, within Sharri National Park (SE). Source: Kosovo Environmental Protection Agency (KEPA)

\section{Material and Methods}

\subsection{Study area}

In Kosovo, the Law on Nature Protection (Law No. 03/L-233) is compiled partially in accordance with the IUCN Protected Area Categories System (Dudley, 2008) and classifies the protected areas into seven categories: Strict nature reserve, National park, Special protected area, Nature Park, Nature monument, Protected landscape and Park architecture 
monument. In MESP (2017) it was estimated that 10.9\% of Kosovo's land area is protected, located within a total of 116 sites altogether covering an area of almost 120.000 ha.

Within these protected areas, besides others (Fig. 1), there are two declared National Parks (NP): "Sharri NP" and "Bjeshkët e Nemuna NP" - that comprise majority of all protected areas.

It is well known that in Luboten there is a great presence of endemic and endangered plant species (Rexhepi, 1984, Berisha et al., 2020), with 26 taxa enlisted in the Red book of vascular flora of Kosovo (Millaku ed., 2013) - out of whom, 5 species are critically endangered ones (CR - IUCN). These data make Luboten an important center for Kosovo's biodiversity and a key part of the Sharri National Park. Therefore, we used mountain massif of Luboten, as a case study to address questions concerning the ecological effectiveness of protected areas in developing countries like Kosovo.

The research was conducted in the mountain massif of Luboten which is located between $42^{\circ} 11^{\prime}-42^{\circ} 13^{\prime} \mathrm{N}$ and $21^{\circ} 07^{\prime}-21^{\circ} 09^{\prime} \mathrm{E}$ in Kosovo. It represents the initial mountain massif in the chain of mountains from the southern part of Sharri NP. The designated park area of Luboten consists of more than 2.000 ha - where beech forests are dominant up to $1550 \mathrm{~m}$ a.s.l. and from there up to the summit (2498 $\mathrm{m}$ a.s.l.) it is predominantly made out of grasslands - along with debris, quarries and some rocky cliffs. Annual rainfall ranges is between 900 and $1100 \mathrm{~mm}$ (Ivanović et al., 2016). The studied area consists of upper mountain zone, in particular areas close to water sub-alpine springs and along the water streams. For comparison reasons, we have studied also plant communities from phytosociological and floristic aspects in the summit of the mountain, as well as analyzed its natural habitat types. This due to that they constitute habitats of the strictly protected area of the National Park.

\subsection{Sampling design and data collection}

Vegetation sampling was carried out from April to August 2019. The studied area was divided into three parts: natural water spring habitats $(\mathrm{NWH})$, degraded water spring habitats (DWH), grasslands (GRAS). Parts with NWH and DWH are located outside and GRAS is within strictly protected area. In total 45 phytosociological relevés (30 relevès $50 \mathrm{~m}^{2}$ and 15 relevés $100 \mathrm{~m}^{2}$ ) were collected, in all three studied parts. The first set of 30 relevés were all situated within the same habitats (natural: 15 relevés, and degraded: 15 relevés) along water streams down to the montane beech forests where these habitats ended. The other set of 15 relevès were conducted in the grasslands of the upper part of the massif, all within the strictly 
protected area. In each area of relevé, all plant taxa were identified to species level and besides of phytosociological analysis they were counted (for taxonomic diversity indices). Phytosociological studies were conducted according to the classical methodology of the Zürich-Montpellier school (Braun-Blanquet, 1964), where for each relevé notes were taken concerning: inclination (in degree), exposition, altitude (m a.s.l.), total plant cover (in \%), substrate type and locality coordinates. In addition to the phytosociological aspect, and as a result of group work (and careful marking of relevés on site), as well as due to repeated onfield measurements in many time periods, it was managed to include in calculations all plant species that grow in these habitats during the entire vegetation period.

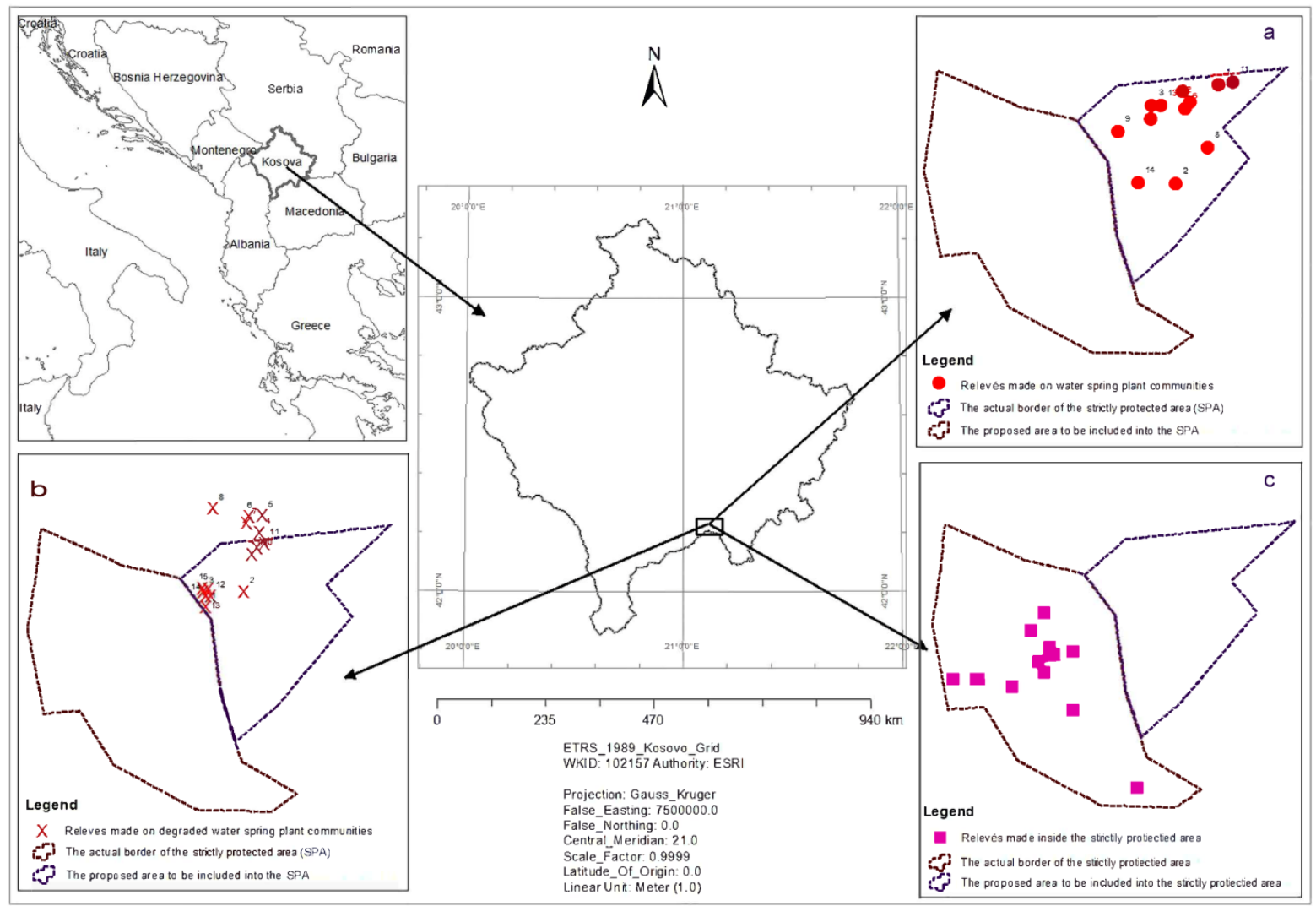

Figure 2. Depiction of relevés made on a) natural water spring habitats, b) degraded water spring habitats and c) grasslands. Encircled in red is the actual border of the Strictly protected area while in bluish (right side) is the area proposed for inclusion within the strictly protected area

\subsection{Data analysis}

For identification, description and classification of plant communities, comprehensive vegetation tools and analysis were used (EEA, 2014; Moss, 2008). Main criteria for 
classifying the vegetation were: physiognomy (growth and life form), floristic properties (dominant species), environment (habitat type, soil), geographical location and community succession stage (Ellenberg, 1973).

Three different indices were used to characterize species diversity in different surveyed habitats (NWH, DWH, GRAS). They were: $(S)$ species richness - the number of species for $50 \mathrm{~m}^{2}$ (in relevés with $100 \mathrm{~m}^{2}$, the obtained value was divided by 2), $(H)$ Shanon's diversity index $H^{\prime}=-\sum_{i=1}^{S} \mathrm{P}_{\mathrm{i}} \log _{2} \mathrm{P}_{\mathrm{i}}$ - a mathematical measure of species diversity in a community. Where: $p$ is the proportion $(\mathrm{N})$ of individuals of one particular species found $(n)$ divided by the total number of individuals found $(N), \ln$ is the natural $\log , \Sigma$ is the sum of the calculations, and $s$ is the number of species. And third, the inverse of Simpson's index, SI = $1 / \lambda$ - as a measure of diversity which emphasizes differences in common species and additionally takes into account the number of present species as well as each species' relative abundance (Magurran, 2004).

For Shannon's diversity index and inverse of Simpson's plots species richness separate paired t-tests (between NWH and DWH; and GRAS and DWH) were made. The paired t-tests were also applied in order to analyze the effects of human disturbance on plant species richness. In order to examine diversity along the transect habitats between two zones of protection, for three habitat types (Shannon's DI) single classification ANOVA was performed.

\section{Results}

\subsection{Vegetation analysis and corresponding natural habitats}

Studied vegetation includes tall-herb vegetation on acidic soils along mountain streams and water springs at high altitudes (Cirsion appendiculati Horvat et al. 1937). On this group, we have two, floristically distinctive entities, one that is natural and the other one that is heavily degraded. Both of these plant communities are not incorporated within the strictly protected area of the mountain. For comparison and study reasons, due to their situation inside of the strictly protected area, we have studied the high mountain grasslands (one dominated by Festuca adamovicii (St.-Yves) Markgr.-Dann. and the other by Dryas octopetala L.).

Herein, a general description of these communities is provided.

The first group of natural water spring habitats (NWH - Annex I) constitute a unique habitat type - E5.5721 Moesian Balkan thistle tall herb communities (Moss, 2008), with 
Cirsium appendiculatum Griseb., as the most distinctive plant species. Syntaxonomically, this plant community belongs to the Class: Mulgedio-Aconitetea Hadač et Klika in Klika et Hadač 1944, Order: Adenostyletalia alliariae Br.-B1. 1930 and the Alliance: Cirsion appendiculati Horvat et al. 1937 - that encompasses all of the tall-herb vegetation on acidic soils along mountain streams and water springs at high altitudes of the Eastern and Central Balkans. The plant association Doronico gigantei-Cirsietum appendiculati Horvat ex Quezel 1969 Quezel, 1969. From 15 collected relevés a total of 76 plant taxa were recorded, with a range of taxa per relevé from 42 to 53 . The average plant cover was $89 \%$. Besides of $C$. appendiculatum as the most distinctive plant species, there were the following as dominant ones: Eriophorum latifolium Hoppe, Cardamine pratensis L. and Helianthemum nummularium (L.) Mill. From 76 recorded taxa, 12 are Balkan endemics and out of them, 5 are listed into the Red Book of Vascular flora of the Republic of Kosovo: Achillea chrysocoma Friv. (EN), Pinguicula balcanica Casper (NT), Gymnadenia frivaldii Hampe ex Griseb. (NT), Pedicularis brachyodonta Schloss. \& Vuk. (LC) and Phyteuma pseudorbiculare Pant. (LC). This plant community is situated outside of the strictly protected area of the mountain.

The second group consists of degraded water spring habitats (DWH - Annex I), that features an altered floristic and physiognomic composition. Due to the degraded nature it possesses, it is rather hard to accurately define its EUNIS habitat type. It resembles to the F2.231 Mountain Juniperus nana scrubs. Syntaxonomically, though they need to be analyzed in more detail and compared further, initially they were classified under the class: VaccinioPiceetea Br.-Bl. in Br.-Bl. et al. 1939. From 15 collected relevés a total of 49 plant taxa were recorded, with a range of taxa per relevé from 30 to 36. The average plant cover was $79 \%$. Dominant taxa were: Rubus idaeus L., Salix caprea L., Epilobium angustifolium L., and Helianthemum nummularium (L.) Mill. From 49 recorded taxa, 5 are Balkan endemics: Bupleurum karglii Vis., Cirsium appendiculatum Griseb., Viola aetolica Boiss. \& Heldr., Onobrychis montana subsp. scardica (Griseb.) P. W. Ball and Dianthus integer Vis. This plant community is also situated outside of the strictly protected area of the mountain (Fig. 2, b.).

The third group encompasses grasslands that are situated inside of the strictly protected area of the mountain. Within this group, two distinctive plant entities were observed, one where Festuca adamovicii (St.-Yves) Markgr.-Dann. was dominant, on silicate base soils and the other, rather scattered, Dryas octopetala L. dominated on limestone substrates. 
Silicate base grasslands of $F$. adamovicii were recorded at high altitudes $>1880 \mathrm{~m}$ a.s.1., where the following species were also abundant: Bromopsis erecta (Huds.) Fourr., Helianthemum nummularium (L.) Mill. and Onobrychis montana subsp. scardica (Griseb.) P. W. Ball, among other taxa (Annex I, Grasslands (Festuca gr.)). They represent closed type of plant community that grows at high altitudes, which are relatively rich on endemic plant species. Despite of endemic species present, they are also distinguished with many moss and lichen species. In total, 54 plant taxa were recorded on this plant community. Average number of taxa per relevé was 40. Out of 54 plant taxa, 9 are Balkan endemics, with Hieracium naegelianum subsp. ljubotenicum $\mathrm{O}$. Behr \& al. as unique plant taxa described from Luboten. Provisional syntaxonomic position of this group is related with the Class: Juncetea trifidi Hadač in Klika et Hadač 1944 and the Order: Seslerietalia comosae Simon 1958. EUNIS Habitat category for this plant community would be: E4.3927 Balkan sub-alpine and alpine Festuca adamovicii grasslands on silicate. This plant group is situated inside of the strictly protected area of the mountain (Fig. 2, c.).

Another set of five relevès were made on Dryas octopetala L. dominated plant communities, that were characterized with more scarce distributional pattern within the strictly protected area. Anyhow, it had a significantly larger number of plant taxa (95) in comparison to the previous group. From them, 17 are Balkan endemics (all endemics are noted in Annex I with **), 7 out of 17 are enlisted in the Red Book of Vascular flora of the Republic of Kosovo, where Achillea chrysocoma Friv. is endangered (EN) species. Provisional syntaxonomic position of this group is related with the Class: Elyno-Seslerietea Br.-B1. 1948 and the Order: Seslerietalia tenuifoliae Horvat 1930. Except of D. octopetala, with high degrees of presences and coverage here were recorded: Carex kitaibeliana Bech., Helianthemum canum (L.) Baumg., Juniperus communis subsp. nana Syme and Oxytropis halleri subsp. korabensis (Kümmerle \& Jáv.) Chrtek \& Chrtková. They comprise the typical EUNIS Habitat of E4.41 Closed calciphile alpine grassland. This plant community as a whole is very important from the biodiversity point of view as its plant species: D. octopetala L., Arctostaphylos uva-ursi (L.) Spreng. and J. communis subsp. nana are categorized as protected into NATURA 2000 Network and as a habitat, the European Union Habitats (European Commission, 2013) categorizes them as "Alpine and Boreal Heaths - 4060 PAL.CLASS.: $31.4 "$ - that should be preserved and properly protected.

\subsection{Species diversity}


Species richness (Fig. 3; The Paired Samples $t$ Test $-P=0.013$ ) as well as Shannon's diversity (Fig. 4; The Paired Samples $t$ Test $-P=0.049$ ) were significantly higher inside the natural water spring habitats (NWH) than in degraded water spring habitats (DWH). Though, this was not a fact between the NWH and the grasslands (GRAS). Simpson's diversity was significantly different between the NWH and the DWH (Fig. 5; The Paired Samples $t$ Test$P=0.037)$. For obtaining these results, corrected $\alpha$ values were applied. Although there have been significantly high environmental degradation in the natural tall herb communities, in certain parts even denaturing them entirely, the remaining ones (Fig. 2a.) have managed to maintain higher taxonomic diversity.

\subsection{Endangered and endemic plant taxa}

A total of 24 Balkan endemic taxa were recorded in the studied area. Out of them, 9 are enlisted into the Red Book of Vascular flora of the Republic of Kosovo (Millaku ed., 2013), evaluated under three risk assessment values (Table 1). The richest communities in terms of endemics and endangered taxa were the Grasslands on limestone substrate, dominated by $D$. octopetala followed by the NWH. While, logically as expected the DWH had the smallest number of taxa in this respect, only 4. From the 8 Red Book enlisted taxa, 4 are categorized as Least Concern (LC), 4 are Near Threatened (NT) and only 1 is Endangered (EN) plant taxa:

Achillea ageratifolia (Sm.) Ben. \& Hook. f.

Table 1. List of recorded Balkan endemics and endangered plant tax.

\begin{tabular}{|c|c|c|c|c|c|c|}
\hline No. & Plant taxa & NWH & DWH & GR- $F$. & Gr- $D$. & R.B. \\
\hline 1. & Achillea abrotanoides (Vis.) Vis. & & & & $\bullet$ & \\
\hline 2. & Achillea ageratifolia $(\mathrm{Sm}$.$) Ben. \& Hook. f.$ & & & & $\bullet$ & NT \\
\hline 3. & Achillea chrysocoma Friv. & $\bullet$ & & $\bullet$ & $\bullet$ & $\mathrm{EN}$ \\
\hline 4. & Alchemilla viridiflora Rothm. & $\bullet$ & & & & \\
\hline 5. & Anthyllis aurea Host & & & & $\bullet$ & \\
\hline 6. & Bupleurum karglii Vis. & & $\bullet$ & & $\bullet$ & \\
\hline 7. & Campanula spatulata $\mathrm{Sm}$. & & & & $\bullet$ & \\
\hline 8. & Cirsium appendiculatum Griseb. & $\bullet$ & $\bullet$ & & & \\
\hline 9. & Dianthus integer Vis. & $\bullet$ & $\bullet$ & $\bullet$ & $\bullet$ & \\
\hline 10. & Dianthus scardicus Wettst. & & & & $\bullet$ & NT \\
\hline 11. & Dianthus sylvestris subsp. bertisceus Rec. f. & & & & $\bullet$ & \\
\hline 12. & Festuca adamovicii (St.-Yv.) Mark.-Dann. & $\bullet$ & & & $\bullet$ & \\
\hline 13. & Gymnadenia frivaldii Hampe ex Griseb. & $\bullet$ & & & & NT \\
\hline 14. & $\begin{array}{l}\text { Hieracium naegelianum subsp. } \\
\text { ljubotenicum } \mathrm{O} \text {. Behr \& al. }\end{array}$ & & & $\bullet$ & $\bullet$ & \\
\hline 15. & Lilium albanicum Griseb. & & & $\bullet$ & & $\mathrm{LC}$ \\
\hline 16. & $\begin{array}{l}\text { Onobrychis montana subsp. scardica } \\
\text { (Griseb.) P. W. Ball }\end{array}$ & $\bullet$ & & & $\bullet$ & \\
\hline
\end{tabular}


17. Oxytropis halleri subsp. korabensis

(Kümmerle \& Jáv.) Chrtek \& Chrtková

18. Pedicularis brachyodonta Schloss. \& Vuk. $\bullet-10$ LC

19. Phyteuma pseudorbiculare Pant. $\quad \bullet \quad \bullet \quad \bullet \quad$ LC

20. Pinguicula balcanica Casper $\quad \bullet \quad \bullet \quad \bullet \quad$ NT

21. Saxifraga scardica Griseb. $\quad \bullet \quad \bullet \quad$ LC

22. Trifolium velenovskyi Vandas

23. Viola aetolica Boiss. \& Heldr. $\bullet \quad \bullet$

24. Willemetia stipitata subsp. albanica

(Kümmerle \& Jáv.) Kirschnerová

Explanations: NWH - Natural Water Spring Habitats, DWH - Degraded Water Spring Habitats, GRF.- Grasslands - Festuca gr., GR-D. - Grasslands - Dryas gr. and R.B. - Red Book of Vascular flora of the Republic of Kosovo (Millaku ed. et al., 2013).

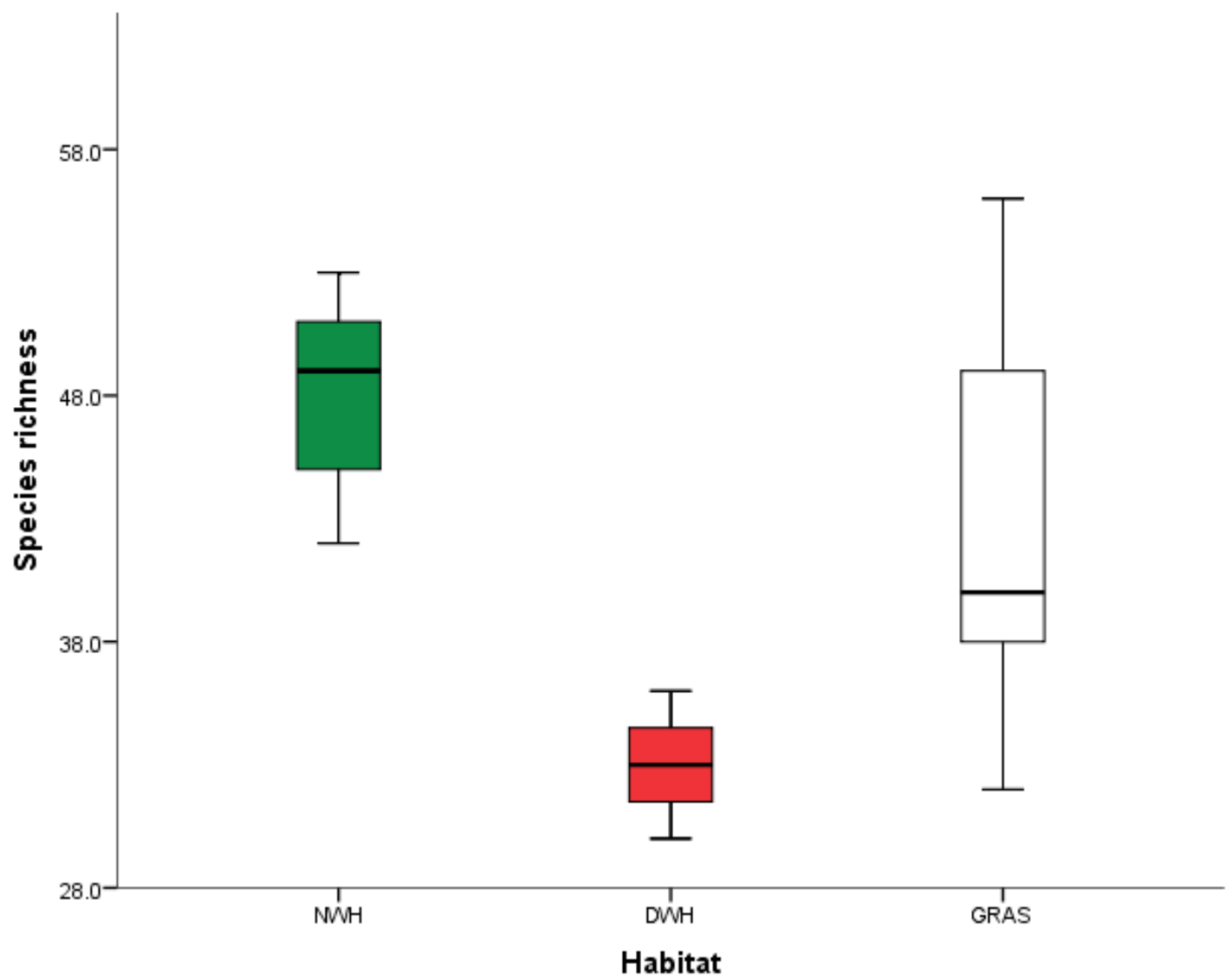

Figure 3. Boxplots of species richness (S) metrics, outlining medians, lower and upper quartiles as well as maximum and minimum data values. NWH - Natural Water Spring Habitats, DWH - Degraded Water Spring Habitats and GRAS - Grassland communities 


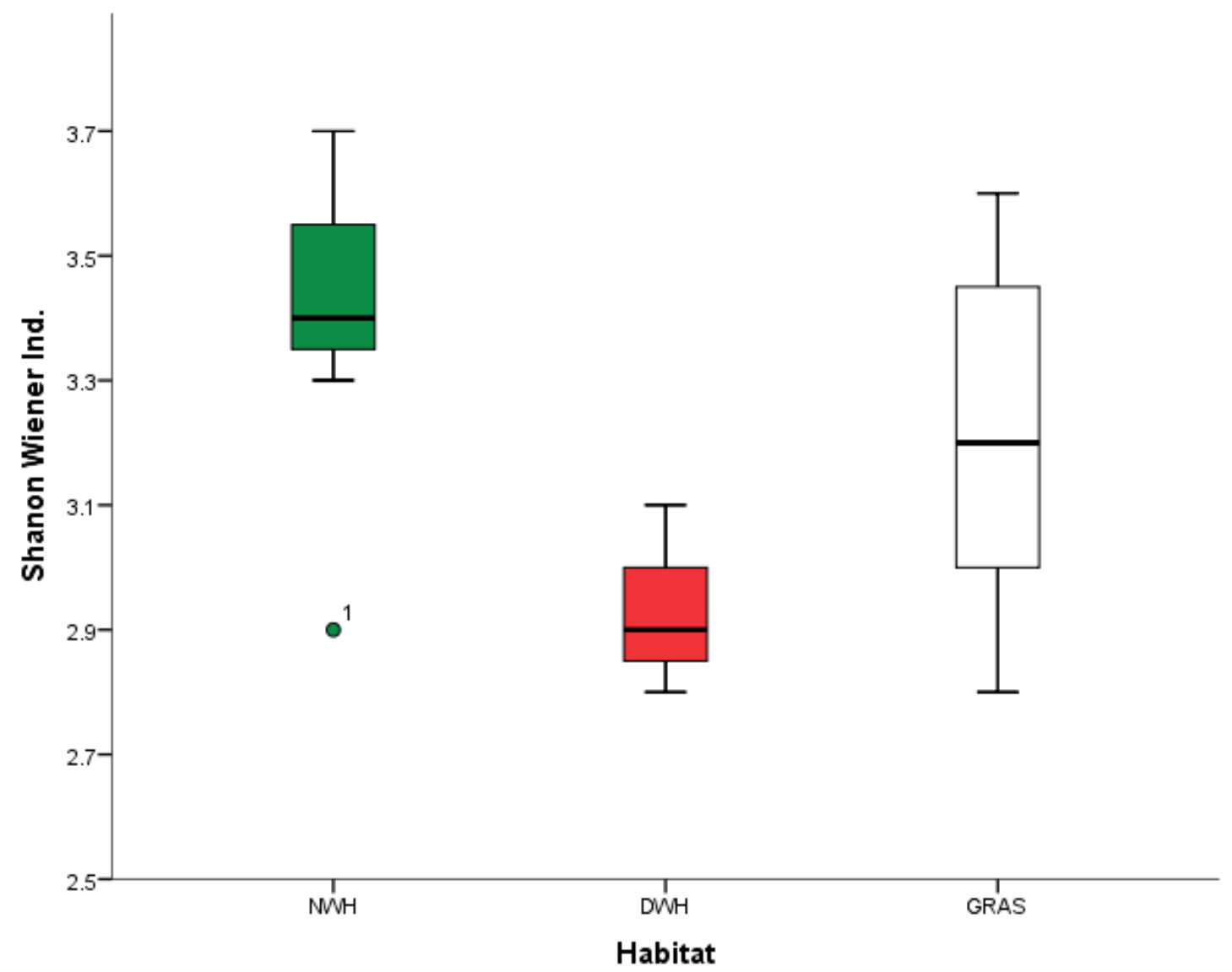

Figure 4. Boxplots of Shanon's Diversity Index $(\mathrm{H})$, outlining medians, lower and upper quartiles as well as maximum and minimum data values. NWH - Natural Water Spring Habitat, DWH - Degraded Water Spring Habitat, expressed a low diversity value and GRAS - Grassland communities belonging to the strictly protected area 


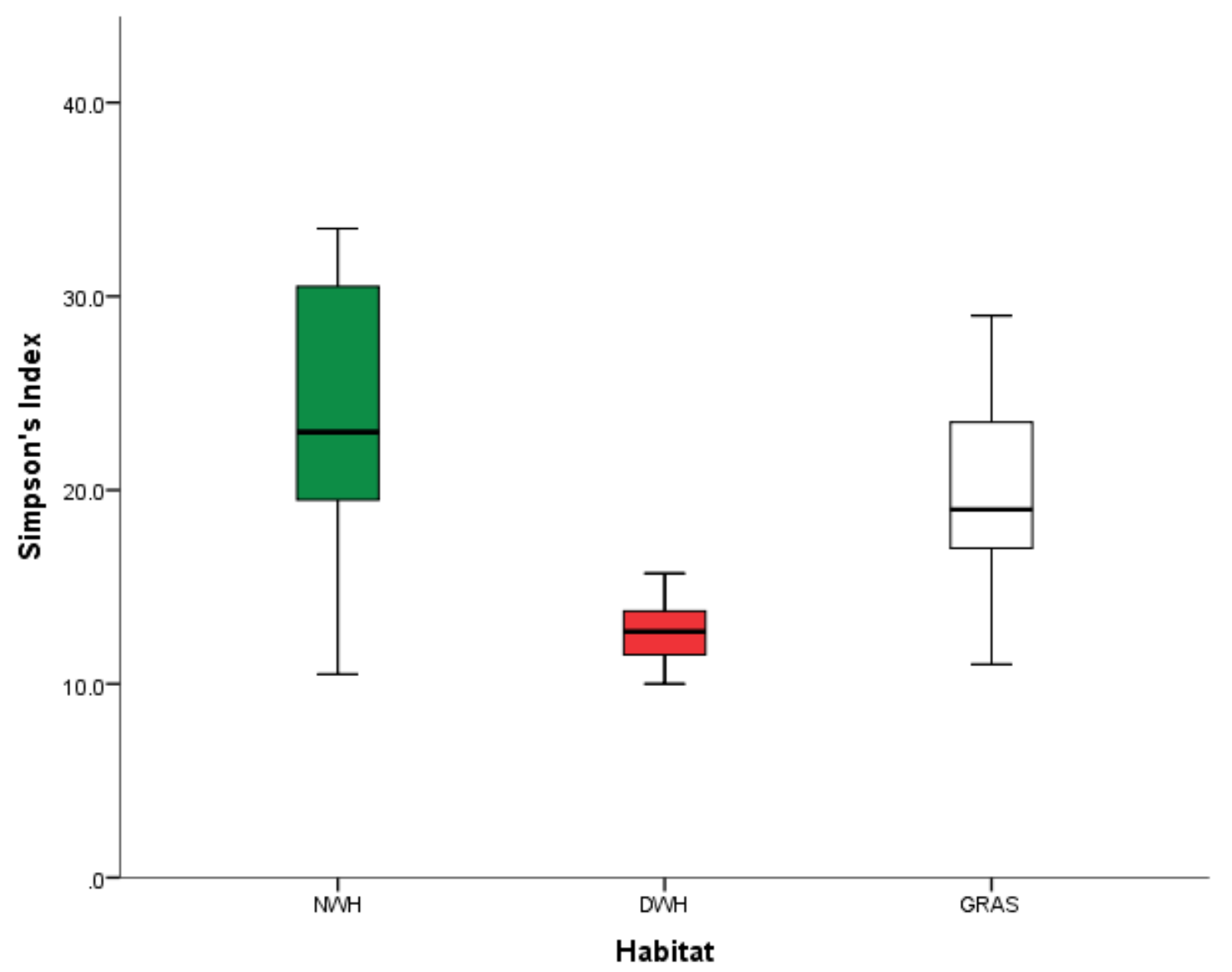

Figure 5. Boxplots of Simpson's index (SI). outlining medians, lower and upper quartiles as well as maximum and minimum data values. NWH - Natural Water Spring Habitat, DWH Degraded Water Spring Habitat, expressed a low SI metrics and GRAS - Grassland communities belonging to the strictly protected area

\section{Discussion}

The conducted diversity pattern analysis in between the three studied habitats revealed that there were significant differences in their diversity composition as well as in regard to their species richness constitution. Moreover, the range of species richness was again higher in natural tall herb communities than in the habitats belonging to the strictly protected area.

The conducted analysis on a continuous basis revealed far higher biodiversity inside the tall herb communities than in degraded ones and also, generally higher diversity compared to the communities belonging the strictly protected area within the massif of Luboten. It is known that freshwater ecosystems compared to others, are characterized with high biodiversity of flora and fauna (Springer \& Stevens, 2009; Warncke, 1980) and globally many of these ecosystems face variety of severe direct or indirect threats (Juutinen, 2011; Puczko et al., 2018). 
In terms of vegetation cover and species constitution, there are many distinct and rare plant communities as well as particular plant taxa that require proper protection and conservation measures within the studied massif of the National Park. Willemetia stipitata (Jacq.) Dalla Torre, as a South-European Orophilous plant species is found only in these small and endangered habitats in Luboten and has never been recorded elsewhere in Kosovo. Additionally, same habitats have Pinguicula balcanica Casper, a Balkan endemic species, characteristic for Habitat E5.5721 (or equivalently, the plant association Doronico giganteiCirsietum appendiculati Horvat ex Quezel 1969 - Quezel, 1969) and enlisted in the Red Book of Vascular Flora of Kosovo (Millaku ed., 2013) as Near Threatened (NT) species; Gymnadenia friwaldii Rchb., categorized in the same list as NT due to very scarce distribution on fragile habitats and Phyteuma pseudorbiculare Pant., categorized as LC (Least Concern) because this species has only six small populations in Kosovo (Millaku ed., 2013). In comparison, the degraded tall herb communities, besides lower diversity values discussed in the previous paragraph, had a considerably smaller number of plant taxa present (49) and they were completely altered into a new and apparent transitory habitat. There, all of the characteristic species of phytocenosis Orphanideo-Cirsietum appendiculati Ht. 1960 were absent, notably Rubus idaeus L., Salix caprea L. and Epilobium angustifolium L. were predominant species (Annex I, Degraded subalpine moist tall herbs plant communities). This came as a direct result of human disturbance into the natural habitat, where the water source had completely been taken over through the pipes down to the villages and no water was left to flow down in its natural course. We have to point out that water springs in the mountains, particularly those at higher altitudes, are not only important sources of water but also a source of key resources such as minerals, energy and supporting backbone for a wide array of agricultural products (Negi \& Joshi, 2002; Caine, 2012; Bundi \& Peter, 2010). Additionally and most importantly, they represent a very subtle storehouse for a unique set of biological diversity.

Although rationales for national parks across the globe are very diverse and widely complex (Michel, 2017), each having its own specifications, the main goal is to offer proper services for nature conservation and to potentially contribute to local economies through tourism (IUCN, 2017; Mayer et al., 2010; Adams, 2010; Thévenot et al., 2000; Küpfer, 2000). When it comes to protected areas in Sharri NP, we have noticed that the effectiveness in preserving and protecting biodiversity is not always the case. Nevertheless, boundaries and zones within NP Sharri, in Luboten area are noticed that not always were set and established with exact conservation aims, based on field pressures and threats. Instead, it seems they were 
chosen based on a variety of other factors including remoteness, areas of least economic value, and habitats with high exquisite aesthetical value (Abukari \& Mwalyosi, 2018; Terborgh \& van Schaik, 2002). Through this we would like to highly encourage the responsible authorities to do alter and fix protection zone borders in accordance with on-field situation of endangered plant taxa and their corresponding habitats.

Additionally, from the conducted study using primarily phytosociological data, we realized that one of the key applications that vegetation studies could yield, besides synsystematics, floristics and other aspects, is that they can provide a sound scientific basis for international measures towards nature protection (Rodwell et al., 2002).

\section{Conclusion}

At the moment, particularly on species-rich Festuca grasslands, there were no detectable threats posed to them of any kind. In contrast, tall herb vegetation along water springs (with exceptional high diversity), faced with a direct threat, the human induced absence of water. A major part of these habitats has already been recorded to be completely destroyed. The factual situation urges us to strongly suggest the extension of 1PA for at least $0.56 \mathrm{~km}^{2}$ into the northwestern direction of the western slope (Fig. 2. Coordinates: $42^{\circ} 12.952 \mathrm{~N} ; 21^{\circ} 08.337 \mathrm{E}$ ) in the massif of Luboten. The only way to save these degrading habitats at the moment would be conduct strict protection, continuous monitoring as well as further studies on other ecological aspects and trends would be of aid.

Such anthropogenic activities represent a serious threat to tall herb vegetation habitats and the whole ecosystem in that area of Sharri National Park. These activities, if not properly handled, in the near future could cause an undesirable cascade of natural changes and in large scale a loss of rare and endangered plant taxa along with their corresponding communities.

\section{Acknowledgements}

For provided help with the maps we are very grateful to Hazir Çadraku (UBT, Kosovo). The Kosovarian Ministry of Environment and Spatial Planning is gratefully acknowledged for granting us the special permission to study in the area of Luboten, Sharri NP (License no. 1770/18/222 - DMMU). Additionally we thank two anonymous reviewers for their constructive comments and suggestions. 


\section{References}

Abukari H. \& Mwalyosi R.B., 2018, Comparing pressures on national parks in Ghana and Tanzania: The case of Mole and Tarangire National Parks. Global Ecol. Conserv. DOI: $10.1016 /$ j.gecco.2018.e00405

Adams W M., 2010, Green development: Environment and sustainability in a developing world, 3rd ed. London \& New York.

Barber Ch.P., Cochrane M.A., Souza C.Jr. \& Verissimo A., 2012, Dynamic Performance Assessment of Protected Areas. Biol. Conserv. 149(1): 6-14. DOI: 10.1016/j.biocon.2011.08.024

Bengtsson J., 1998, Which species? What kind of diversity? Which ecosystem function? Some problems in studies of relations between biodiversity and ecosystem function. Appl. Soil Ecol. 10: 191-199.

Berisha N., Krasniqi E., Millaku F., 2020, A quantitative approach for conservation of endangered and endemic plants from Kosovo, SE Europe. Folia Oecologica 47(1): 5263. DOI: $10.2478 /$ foecol-2020-0007

Braun-Blanquet J., 1964, Pflanzensoziologie - 3rd ed. Springer-Verlag, Wien, New York.

Brown K.A., Ingram J.C., Flynn D.F., Razafindrazaka R. \& Jeannoda V., 2009, Protected Area Safeguard Tree and Shrub Communities from Degradation and Invasion: A Case Study in Eastern Madagascar. Environ. Manage. 44(1): 136-148. DOI: $10.1007 / \mathrm{s} 00267-008-9257-5$

Bundi U. \& Peter A., 2010, Alpine waters - The Handbook of Environmental Chemistry 6. Springer-Verlag, Berlin Heidelberg.

Caine N., 2012, Alpine Waters. Mt. Res. Dev. 32(1): 98-98. DOI:10.1659/mrd.mm094

Chapin F.S., Zavaleta E.S., Eviner V.T., Naylor R.L., Vitousek P.M., Reynolds H.L., Hooper D.U., Lavorel S., Sala O.E., Hobbie S.E., Mack M.C. \& Diaz S., 2000, Consequences of changing biodiversity. Nature 405: 234-242. DOI: 10.1038/35012241

DeFries R., Hansen A., Newton A.C. \& Hansen MC., 2005, Increasing isolation of protected areas in tropical forests over the past twenty years. Ecol. Appl. 15: 19-26. doi.org/10.1890/03-5258

Dìaz S. \& Cabido M., 2001, Vive la diffèrence: plant functional diversity matters to ecosystem processes. Trends Ecol. Evol. 16: 646-655. doi.org/10.1016/S01695347(01)02283-2

Dudley N., (ed.) 2008, Guidelines for applying protected areas management categories. IUCN, Gland, Switzerland, $30 \mathrm{pp}$.

EEA, 2014, Technical report on terrestrial habitat mapping in Europe. Joint MNHN-EEA report. European Environment Agency. Luxembourg. DOI: 10.2800/11055

Ellenberg H., 1973, Die Ökosysteme der Erde: Versuch einer Klassifikation der Ökosysteme nach funktionalen Gesichtspunkten, [in:] H. Ellenberg (ed.), Ökosystemforschung, 235-265. Springer-Verlag, Berlin, Heidelberg, NewYork, 280 pp.

European Commission, 2013, Interpretation Manual of European Union Habitats - EUR 28. A scientific reference document. European Commission, DG-ENV.

Gaston K.J., Charman K., Jackson S.F., Armsworth P.R., Bonn A., Briers R.A., Callaghan C.S.Q., Catchpole R., Hopkins J., Kunin W.E., Latham J., Opdam P., Stoneman R., Stroud D.A. \& Tratt R., 2006, The ecological effectiveness of protected areas: the United Kingdom. Biol. Conserv. 132: 76-87. doi.org/10.1016/j.biocon.2006.03.013

Hockings M., 2003, Systems for assessing the effectiveness of management in protected areas. BioScience $\quad 53(9): \quad$ 823-832. $\quad$ DOI: $\quad 10.1641 / 0006-$ 3568(2003)053[0823:sfateo]2.0.co;2 
Hooper D.U., Chapin F.S., Ewel J.J., Hector A., Inchausti P. \& Lavorel S., 2005, Effects of biodiversity on ecosystem functioning: a consensus of current knowledge. Ecol. Monogr. 75(1): 3-35. doi.org/10.1890/04-0922

IUCN, 2007, World commission on protected areas. http://www.iucn.org/themes/wcpa/ [Accessed: 09/06/2019].

IUCN, 2017, Category II: National Park. https://www.iucn.org/theme/protectedareas/about/protected-areas-categories/category-ii-national-park [Accessed: 11/08/19].

Ivanović R., Valjarević A., Vukoćić D. \& Radovanović D., 2016, Climatic regions of Kosovo. University Thought 6(1): 49-54. DOI: 10.5937/univtho6-10409

Jones G., 2000, Outcomes-based evaluation of management for protected areas - a methodology for incorporating evaluation into management plans, [in:] The Design and Management of Forest Protected Areas: Papers Presented at the Beyond the Trees Conference, 8-11 May 2000, Bangkok, Thailand. World Wide Fund for Nature, Gland Switzerland, pp. 349-358

Juutinen R., 2011, The decrease of rich fen bryophytes in springs as a consequence of largescale environmental loss. A 50 year re-sampling study. Lindbergia 34: 2-8. www.jstor.org/stable/lindbergia.34.2.

Küpfer I., 2000, Die regionalwirtschaftliche Bedeutung des Nationalparktourismus: Untersucht am Beispiel des Schweizerischen Nationalparks. Zernez: Nationalparkforschung Schweiz. Bern.

Law No. 03/L-233 Of Nature Protection. Assembly of the Republic of Kosovo. Published on: 09.11.2010. Official Gazette 85/2010. https://gzk.rksgov.net/ActDetail.aspx?ActID=2716.

Magurran A.E., 2004, Measuring biological diversity. 2nd ed. Blackwell, Oxford, UK.

Mayer M., Müller M., Woltering M., Arnegger J. \& Job H., 2010, The economic impact of tourism in six German national parks. Landscape Urban Plan 97(2): 73-82. DOI:10.1016/j.landurbplan.2010.04.013

MESP, 2017, Report on the state of nature. Ministry of Environment and Spatial Planning. Institute for Protection of Nature of Kosovo, Prishtina.

Michel A.H., 2017, What is a national park for? - Principles of worth in a Swiss national park project. 6th Symposium for Research in Protected Areas. Salzburg, AT, pp. 425427.

Millaku F. (ed.), Rexhepi F., Krasniqi E., Pajazitaj Q., Mala Xh., Berisha N., 2013, The Red Book of vascular flora of the Republic of Kosovo. MESP, Prishtina.

Moss D., 2008, EUNIS habitat classification - a giuide for users. Report EEA, Copenhagen.

Negi G.S. \& Joshi V., 2002, Drinking water issues and development of spring sanctuaries in a mountain watershed in the Indian Himalayas. Mt. Res. Dev. 22: 29-31. https://doi.org/10.1659/0276-4741(2002)022[0029:DWIADO]2.0.CO;2

Petchey O.L. \& Gaston K.J., 2002, Functional diversity (FD), species richness and community composition. Ecol. Lett. 5(3): 402-411. DOI: 10.1046/j.14610248.2002.00339.x

Petchey O.L. \& Gaston K.J., 2006, Functional diversity: Back to basics and looking forward. Ecol. Lett. 9(6): 741-758. DOI:10.1111/j.1461-0248.2006.00924.x

Puczko K., Zieliński P., Jusik S., Kołakowska A. \& Jekatierynczuk-Rudczyk E., 2018, Vascular plant and bryophyte species richness in response to water quality in lowland spring niches with different anthropogenic impacts. Environ. Monit. Assess. 190(6): 338. DOI: $10.1007 / \mathrm{s} 10661-018-6703-6$

Quezel P., 1969, La végétation du massif de Bela Voda (Macédonia Nord-Occidentale). Biologia Gallo-Hellenica 2(2): 93-112. 
Rexhepi F., 1984, Flora of Luboten, Sharri Mountains, Kosovo. Nature of Kosovo 2(3): 2754. EKMN, Prishtina.

Rodwell J.S., Schaminée J.H.J., Mucina L., Pignatti S., Dring J. \& Moss D., 2002, An overview of phytosociological alliances and their relationships to EUNIS habitats. Research report. EC-LNV (Rapport EC-LNV 2002/054). Wageningen, the Netherlands.

Rowell T.A., 1993, Common Standards for Monitoring SSSIs. Joint Nature Conservation Committee, Peterborough, UK.

Springer A.E. \& Stevens L.E., 2009, Spheres of discharge of springs. Hydrogeol J. 17: 83-93. doi.org/10.1007/s10040-008-0341-y

Terborgh J. \& van Schaik C., 2002, Why the world needs parks, [in:] J,Terborgh, C.V. Schaik, L. Davenport, M. Rao (eds), Making parks work: strategies for preserving tropical nature. Island Press, Washington, DC, pp. 3-14.

Thévenot L., Moody M. \& Lafaye C., 2000, Forms of valuing nature: arguments and modes of justification in French and American environmental disputes, [in:] M. Lamont, L. Thévenot (eds), Rethinking comparative cultural sociology; repertoires of evaluation in France and the United States. Cambridge University Press, Cambridge, UK, pp. 229-272.

Tilman D., 1999, The ecological consequences of changes in biodiversity: a search for general principles. Ecology 80: 1455-1474.

Tilman D., 2001, Functional diversity, [in:] S.A. Levin (ed.) Encyclopaedia of Biodiversity. Academic Press, San Diego, CA, pp. 109-120.

Tuya F., Garcia-Diez C., Espino F. \& Haroun R.J., 2006, Assessment of the effectiveness of two marine reserves in the Canary Islands (eastern Atlantic). Ciencias Marinas 32(3): 505-522. DOI: $10.7773 / \mathrm{cm} . v 32 \mathrm{i} 3.1133$

Warncke E., 1980, Spring areas: ecology, vegetation, and comments on similarity coefficients applied to plant communities. Holarctic Ecol. 3: 233-308.

Wilshusen P.R., Brechin S.R., Fortwangler C.L. \& West P.C., 2003, Contested nature: conservation and development at the turn of the twenty-first century, [in:] S.R. Brechin, P.R. Wilshusen, C.L. Fortwangler, P.C. West (eds) Contested nature: promoting international biodiversity with social justice in the twenty-first century. State University of New York Press, Albany, pp. 1-22. 
Annex I. Phytosociological relevès

\begin{tabular}{|c|c|c|c|c|c|c|c|c|c|c|c|c|c|c|c|}
\hline \multicolumn{16}{|l|}{$\begin{array}{l}\text { Natural Water Spring Habitats } \\
(\mathrm{NWH})\end{array}$} \\
\hline Number of relevé & 1 & 2 & 3 & 4 & 5 & 6 & 7 & 8 & 9 & 10 & 11 & 12 & 13 & 14 & 15 \\
\hline Plot area & 50 & 50 & 50 & 50 & 50 & 50 & 50 & 50 & 50 & 50 & 50 & 50 & 50 & 50 & 50 \\
\hline Inclination in degree & 18 & 10 & 15 & 15 & 10 & 20 & 15 & 18 & 10 & 18 & 15 & 14 & 15 & 15 & 15 \\
\hline Exposition & $\mathrm{E}$ & SE & SE & SE & SE & NW & NW & NW & $\mathrm{N}$ & NW & $\mathrm{N}$ & NW & NW & NW & SE \\
\hline Altitude (m.a.s.l) & 1737 & 1732 & 1718 & 1686 & 1664 & 1974 & 1989 & 1989 & 1802 & 1989 & 1884 & 1901 & 1909 & 1911 & 1847 \\
\hline Covering (\%) & 98 & 98 & 80 & 80 & 90 & 85 & 85 & 85 & 85 & 85 & 95 & 90 & 95 & 85 & 98 \\
\hline Substrate & Silicate & Silicate & Silicate & Silicate & Silicate & Silicate & Silicate & Silicate & Silicate & Silicate & Silicate & Silicate & Silicate & Silicate & Silicate \\
\hline Locality & Luboten & Luboten & Luboten & Luboten & Luboten & Luboten & Luboten & Luboten & Luboten & Luboten & Luboten & Luboten & Luboten & Luboten & Luboten \\
\hline $\begin{array}{l}\text { Number of species per relevé } \\
\text { Date }\end{array}$ & $\begin{array}{c}43 \\
10.06 \\
2019\end{array}$ & $\begin{array}{c}42 \\
10.06 \\
2019\end{array}$ & $\begin{array}{c}40 \\
10.06 \\
2019\end{array}$ & $\begin{array}{c}42 \\
10.06 \\
2019\end{array}$ & $\begin{array}{c}45 \\
10.06 \\
2019\end{array}$ & $\begin{array}{c}52 \\
07.07 \\
2019\end{array}$ & $\begin{array}{c}44 \\
10.07 \\
2019\end{array}$ & $\begin{array}{c}45 \\
10.07 \\
2019\end{array}$ & $\begin{array}{c}46 \\
18.07 \\
2019\end{array}$ & $\begin{array}{c}50 \\
18.07 \\
2019\end{array}$ & $\begin{array}{c}53 \\
05.07 \\
2019\end{array}$ & $\begin{array}{c}50 \\
05.07 \\
2019\end{array}$ & $\begin{array}{c}52 \\
05.07 \\
2019\end{array}$ & $\begin{array}{c}49 \\
05.07 \\
2019\end{array}$ & $\begin{array}{c}50 \\
05.07 \\
2019\end{array}$ \\
\hline GPS Coordinates & 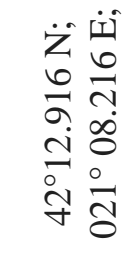 & 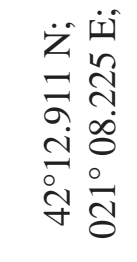 & 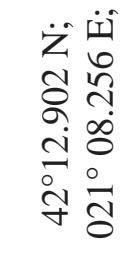 & 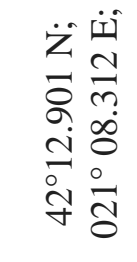 & 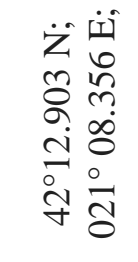 & 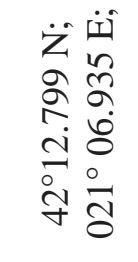 & 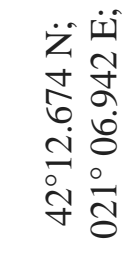 & 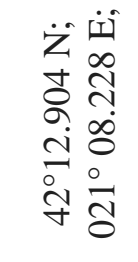 & 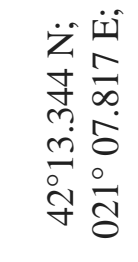 & 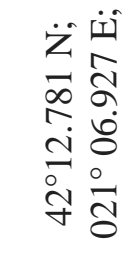 & 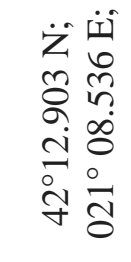 & 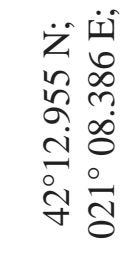 & 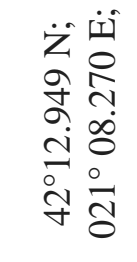 & 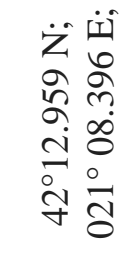 & 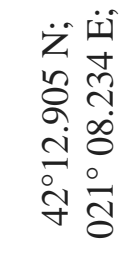 \\
\hline Cirsium appendiculatum ** & 2 & 3 & 2 & 2 & 3 & + & 1 & 3 & 3 & 2 & 4 & 3 & 4 & 3 & 4 \\
\hline Eriophorum latifolium & + & 1 & + & + & 2 & 3 & 2 & 2 & 2 & 3 & 3 & 2 & 2 & 1 & 2 \\
\hline Cardamine pratensis & + & 1 & 1 & 1 & + & 1 & + & + & 2 & 1 & 3 & 2 & 2 & 2 & 2 \\
\hline Helianthemum nummularium & 2 & + & + & 3 & 2 & + & + & 2 & + & + & 1 & 1 & 2 & 1 & 1 \\
\hline Pinguicula balcanica $\quad * *$ & 1 & . & + & + & 1 & 1 & 3 & 1 & 1 & 1 & 1 & 1 & 1 & 2 & 1 \\
\hline Luzula sylvatica & 1 & + & + & . & + & + & + & + & . & + & . & 1 & + & . & + \\
\hline Dactylorhiza maculata & + & 1 & + & . & . & 1 & + & . & 1 & 1 & 2 & 1 & 1 & 1 & + \\
\hline Carex curvula & + & + & + & . & 1 & 1 & 1 & 1 & 1 & + & 1 & 2 & 1 & 1 & + \\
\hline Bromopsis erecta & + & + & + & + & 1 & 1 & + & 1 & + & 1 & 1 & + & 1 & + & + \\
\hline Alchemilla hybrida & + & + & + & + & + & + & + & + & + & + & 1 & 2 & 1 & 2 & 1 \\
\hline Musci sp. & + & 1 & + & + & . & + & + & . & 1 & + & + & + & + & + & \\
\hline Pimpinella saxifraga & + & + & + & . & + & + & + & + & + & + & + & + & . & + & + \\
\hline Geum coccineum & + & + & + & + & . & + & + & + & + & . & + & + & + & 1 & 2 \\
\hline $\begin{array}{l}\text { Trifolium badium } \\
\text { Calamagrostis varia subsp. }\end{array}$ & + & + & . & + & + & + & + & . & + & . & . & 1 & + & 1 & 1 \\
\hline varia & + & 1 & 2 & 2 & 1 & + & + & . & + & + & + & . & . & . & . \\
\hline
\end{tabular}


Caltha palustris

Mentha longifolium

Oenanthe peucedanifolia

Stellaria alsine

Doronicum austriacum

Veratrum lobelianum

Phleum alpinum

Ranunculus breyninus

Rhamnus alpina susbp. fallax Alchemilla viridiflora *

Juncus effusus

Blysmus compressus

Festuca adamovicii

Juniperus communis subsp.

nana

Arabis ciliata

Veronica chamaedrys

Plantago lanceolata

Geranium sylvaticum

Trifolium repens

Myosotis sylvatica

Athyrium filix-femina

Onobrychis montana subsp. scardica **

Stachys alopecurus

Salix caprea

Poa molinerii

Primula elatior

Fragaria vesca

Saxifraga rotundifolia

Daphne mezerum

Silene pusilla

Bistorta vivipara

Juncus thomasii

Viola aetolica **

\begin{tabular}{|c|c|c|c|c|c|c|c|c|c|c|c|c|c|c|}
\hline+ & 1 & 1 & + & + & + & . & . & 1 & + & + & + & + & + & + \\
\hline+ & + & 1 & 1 & 1 & + & . & + & + & + & + & + & + & + & + \\
\hline+ & + & 1 & + & . & + & + & + & + & + & + & + & + & + & . \\
\hline+ & + & . & + & + & . & + & . & + & . & + & + & + & + & + \\
\hline+ & + & . & + & + & . & . & + & + & + & + & + & . & . & . \\
\hline+ & + & + & . & + & + & + & + & + & + & + & 1 & . & + & + \\
\hline+ & + & . & . & + & + & + & + & + & + & . & . & . & . & + \\
\hline+ & + & . & + & + & + & + & + & + & . & . & + & . & + & 1 \\
\hline+ & + & + & . & + & + & + & . & + & + & + & + & + & 1 & + \\
\hline+ & + & + & . & + & + & + & . & + & + & + & . & + & + & . \\
\hline+ & + & + & + & + & + & + & + & + & + & + & + & + & + & + \\
\hline+ & + & . & . & . & + & + & . & . & + & + & 1 & . & + & 2 \\
\hline+ & 1 & + & . & . & . & . & + & 1 & . & + & + & + & + & . \\
\hline+ & + & 1 & . & + & + & . & . & + & . & + & . & + & . & + \\
\hline+ & + & . & . & . & + & . & + & . & + & + & . & + & + & + \\
\hline+ & + & . & . & 1 & + & . & + & + & . & + & + & . & . & + \\
\hline+ & + & + & . & + & + & + & . & + & . & + & . & . & + & + \\
\hline+ & . & + & + & . & + & + & . & . & . & + & + & + & . & . \\
\hline+ & . & + & . & . & + & + & + & . & + & + & + & + & . & . \\
\hline+ & . & + & . & + & + & + & . & . & + & + & + & . & + & + \\
\hline+ & . & + & + & . & + & + & . & + & . & + & . & . & + & . \\
\hline+ & . & + & + & . & . & + & + & . & . & . & + & . & + & . \\
\hline+ & . & + & . & . & . & + & . & . & + & + & . & + & + & + \\
\hline+ & . & + & + & + & . & . & + & . & + & . & . & + & + & 1 \\
\hline+ & . & . & + & 1 & . & . & . & . & . & . & . & + & . & . \\
\hline+ & . & . & + & + & + & . & + & . & + & + & + & + & . & + \\
\hline+ & . & . & + & . & + & + & . & . & + & + & . & + & + & + \\
\hline+ & . & . & . & . & + & + & + & . & + & + & 2 & + & 1 & 1 \\
\hline+ & . & . & . & . & + & + & + & . & . & . & . & + & + & . \\
\hline . & + & + & . & + & + & + & + & + & + & + & + & . & + & + \\
\hline . & + & + & . & . & + & + & + & + & + & + & + & + & + & + \\
\hline . & + & + & . & . & + & + & + & + & + & + & . & + & + & + \\
\hline . & + & . & + & 2 & + & + & + & + & + & + & + & + & + & . \\
\hline
\end{tabular}


Deschampsia cespitosa

Dianthus integer **

Rumex acetosa

Willemetia stipitata subsp.

albanica

Galium palustre

Urtica dioica

Viola gracilis

Carex kitaibelliana

Thalictrum aquilegifolium

Gymnadenia frivaldii

Thymus praecox sbusp.

zygiformis

Rubus idaeus

Ornithogalum gussonei

Agrostis canina

Veronica serpyllifolia

Achillea chrysocoma

Geranium robertianum

Clinopodium acinos

Cystopteris fragilis

Saxifraga adscendens

Pedicularis brachyodonta

Phyteuma pseudorbiculare

**

Senecio squalidus subsp.

rupestris

Leontodon crispus

Epilobium montanum

Myosotis suaveolens

Anemonastrum narcissiflorum

Senecio nemorensis

Degraded Water Spring

Habitats (DWH)

Number of relevé

Plot area

1
50

1
50

2
50

3
50

4
50

4
50

5
50

7
50

8
50

9
50

9
50

1

10
50

11
50

11
50

12

13
50

14
50

15
50 


\begin{tabular}{|c|c|c|c|c|c|c|c|c|c|c|c|c|c|c|c|}
\hline Inclination in degree & 15 & 10 & 12 & 15 & 10 & 10 & 10 & 15 & 15 & 10 & 15 & 15 & 10 & 15 & 15 \\
\hline Exposition & $\mathrm{N}$ & $\mathrm{N}$ & $\mathrm{NE}$ & $\mathrm{N}$ & NW & $\mathrm{N}$ & $\mathrm{N}$ & $\mathrm{N}$ & $\mathrm{NE}$ & $\mathrm{N}$ & NW & $\mathrm{N}$ & $\mathrm{N}$ & $\mathrm{N}$ & $\mathrm{N}$ \\
\hline Altitude (m.a.s.l) & 1801 & 1795 & 1815 & 1749 & 1766 & 1704 & 1788 & 1727 & 1809 & 1795 & 1747 & 1750 & 1738 & 1712 & 1722 \\
\hline Covering (\%) & 80 & 75 & 80 & 70 & 85 & 75 & 80 & 80 & 90 & 85 & 75 & 70 & 80 & 85 & 75 \\
\hline Substrate & Silicate & Silicate & Silicate & Silicate & Silicate & Silicate & Silicate & Silicate & Silicate & Silicate & Silicate & Silicate & Silicate & Silicate & Silicate \\
\hline Locality & Luboten & Luboten & Luboten & Luboten & Luboten & Luboten & Luboten & Luboten & Luboten & Luboten & Luboten & Luboten & Luboten & Luboten & Luboten \\
\hline $\begin{array}{l}\text { Number of species per relevé } \\
\text { Date }\end{array}$ & $\begin{array}{c}35 \\
10.06 . \\
2019\end{array}$ & $\begin{array}{c}31 \\
10.06 . \\
2019\end{array}$ & $\begin{array}{c}32 \\
10.06 \\
2019\end{array}$ & $\begin{array}{c}34 \\
10.06 \\
2019\end{array}$ & $\begin{array}{c}30 \\
10.06 \\
2019\end{array}$ & $\begin{array}{c}32 \\
25.06 . \\
2019\end{array}$ & $\begin{array}{c}35 \\
25.06 . \\
2019\end{array}$ & $\begin{array}{c}33 \\
25.06 \\
2019\end{array}$ & $\begin{array}{c}36 \\
25.06 \\
2019\end{array}$ & $\begin{array}{c}30 \\
06.07 \\
2019\end{array}$ & $\begin{array}{c}33 \\
06.07 \\
2019\end{array}$ & $\begin{array}{c}35 \\
06.07 . \\
2019\end{array}$ & $\begin{array}{c}34 \\
06.07 \\
2019\end{array}$ & $\begin{array}{c}30 \\
06.07 \\
2019\end{array}$ & $\begin{array}{c}33 \\
06.07 \\
2019\end{array}$ \\
\hline GPS Coordinates & 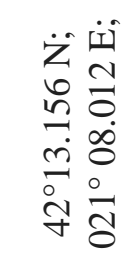 & 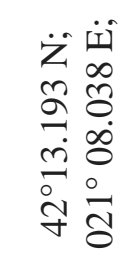 & 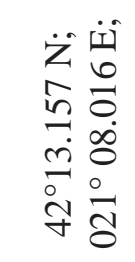 & 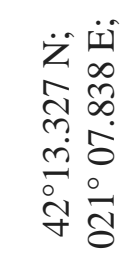 & 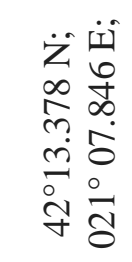 & 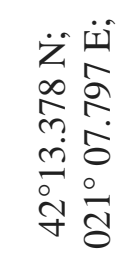 & 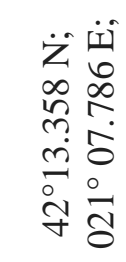 & 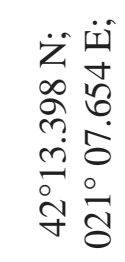 & 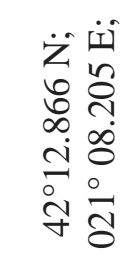 & 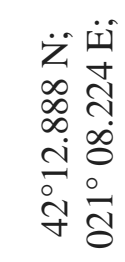 & 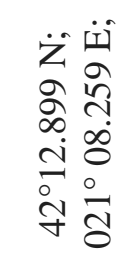 & 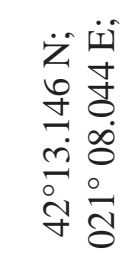 & 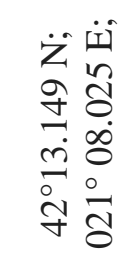 & 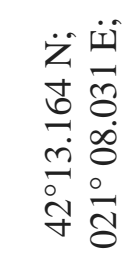 & 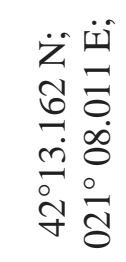 \\
\hline Rubus idaeus & 4 & 4 & 3 & 4 & 4 & 3 & 4 & 4 & 4 & 4 & 3 & 4 & 4 & 4 & 3 \\
\hline Epilobium angustifolium & 2 & 1 & 3 & 2 & 2 & 2 & 2 & 3 & 2 & 3 & 3 & 2 & 2 & 2 & 2 \\
\hline Helianthemum nummularium & 1 & 1 & 1 & 1 & 1 & 1 & 1 & 1 & 1 & 1 & 1 & 1 & 1 & 1 & 1 \\
\hline Achillea atrata & 1 & 1 & 1 & + & 1 & + & + & 1 & 1 & + & + & + & + & 1 & 1 \\
\hline Ptilostemon afer & + & + & 1 & + & . & 1 & 1 & + & + & 1 & + & + & 1 & . & + \\
\hline Achillea setacea & + & . & + & 1 & 1 & + & 1 & 1 & 1 & + & 1 & 1 & 1 & 1 & 1 \\
\hline Carduus acanthoides & + & + & + & + & + & 1 & + & 2 & + & + & 1 & + & 1 & + & + \\
\hline $\begin{array}{l}\text { Juniperus communis subsp. } \\
\text { nana }\end{array}$ & + & + & . & + & + & + & + & 1 & . & + & . & + & + & + & + \\
\hline Carlina acaulis & + & + & . & + & + & + & + & + & + & . & + & . & + & + & + \\
\hline Senecio nemorensis & + & + & + & + & + & + & + & + & + & + & . & + & + & + & . \\
\hline Bupleurum karglii ** & + & + & + & + & + & + & + & . & + & + & + & + & + & + & . \\
\hline Trinia dalechampii & + & + & + & . & + & . & . & + & + & + & + & . & . & + & + \\
\hline Veratrum lobelianum & + & + & + & + & + & + & + & + & + & + & + & + & . & + & . \\
\hline Neotinea maculata & + & + & + & + & . & + & + & + & + & + & . & + & + & . & + \\
\hline Luzula sudetica & + & + & + & + & + & + & + & + & + & + & + & + & + & + & . \\
\hline Deschampsia caespitosa & + & . & + & + & . & . & + & · & + & . & + & + & + & . & + \\
\hline Phleum alpinum & + & + & . & + & + & . & + & + & + & + & + & + & + & + & + \\
\hline Sesleria juncifolia & + & + & + & . & . & + & . & + & . & + & + & . & . & . & + \\
\hline
\end{tabular}


Caltha palustris

Gentiana utriculosa

Ranunculus montanus

Sedum ochroleucum

Saxifraga adscendens

Parnassia palustris

Hypericum perforatum

Saxifraga aizoides

Populus tremula

Viola aetolica **

Genista depressa

Trifolium badium

Onobrychis montana subsp. scardica

Trifolium repens

Geum montanum

Rosa pendulina

Rhamnus alpina subsp. fallax

Geum coccineum

Acer platanoides

Daphne mezerum

Phyllolepidium rupestre

Rumex acetosella

Dianthus integer **

Scleranthus perennis

Silene vulgaris

Vaccinium uliginosum

Galium pumillum

Noccaea bellidifolia

Veronica chamaedrys

Grasslands (Festuca gr.) -

belonging to the Strictly

Protected Area

Number of relevé

2

3

4

5

6

8

9

10

11

12

13

14 


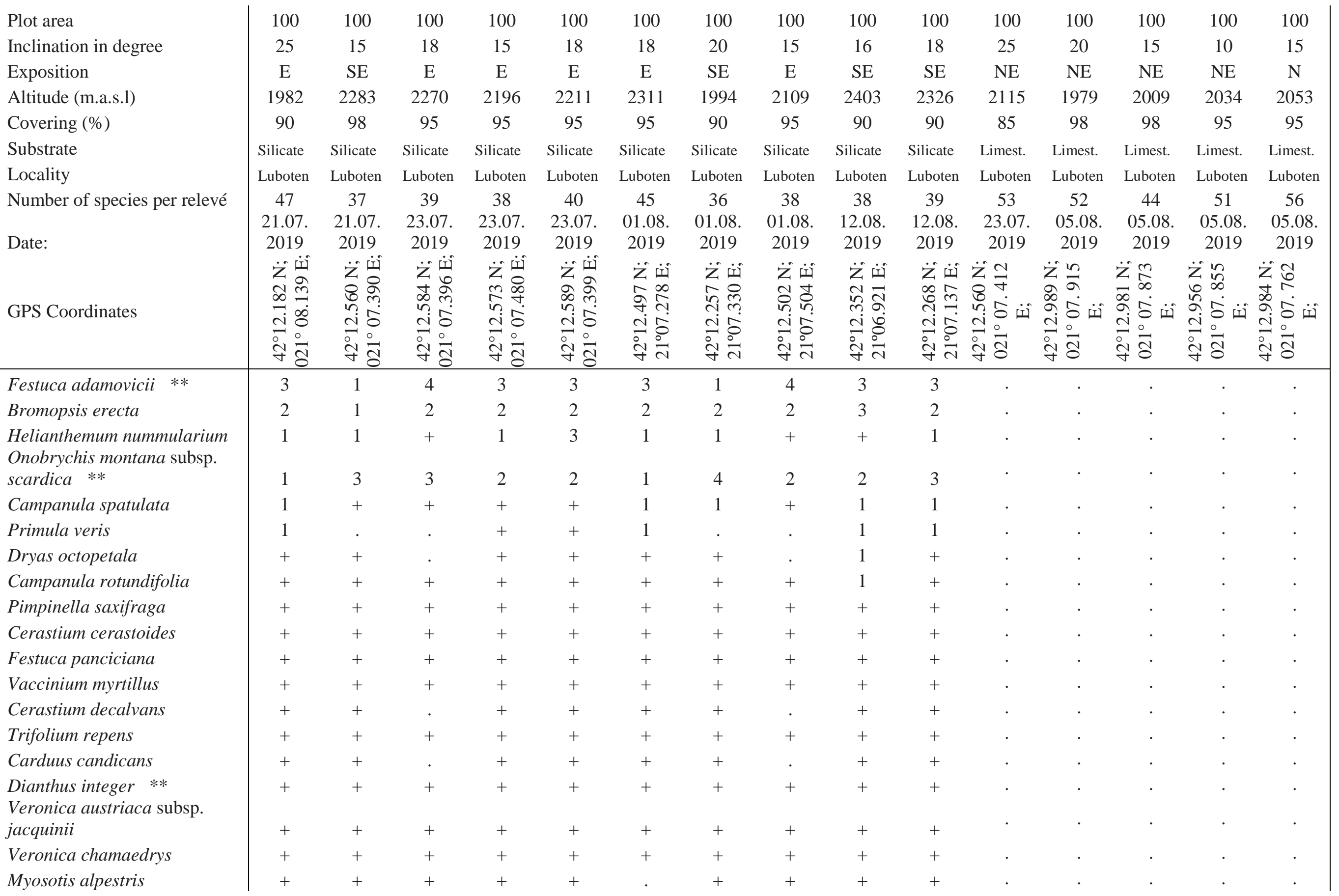


Lilium albanicum ** Asperula cynanchica Arctostapyhlos uva-ursi Juniperus communis subsp. nana

Carex kitaibeliana Phleum montanum Saxifraga scardica ** Bistorta vivipara Alchemilla plicatula Koeleria eriostachya Leontodon crispus Hieracium naegelianum subsp. ljubotenicum ** Trifolium badium

Ranunculus montanus Scabiosa columbaria

Trifolium noricum Senecio squalidus subsp. rupestris

Myosotis sylvatica

Galium anisophyllon Dianthus sylvestris

Trifolium velenovskyi Saxifraga paniculata Cyanus triumfettii Geum montanum Polygala major Trifolium alpestre Sedum ochroleucum Achillea chrysocoma ** Arctostaphylos uva-ursi Iberis sempervirens Helianthemum canum Nardus stricta

\begin{tabular}{|c|c|c|c|c|c|c|c|c|c|c|c|c|c|c|}
\hline+ & . & + & . & + & + & . & + & . & + & . & . & . & . & . \\
\hline+ & . & + & + & . & + & . & + & + & . & . & . & . & . & . \\
\hline+ & . & + & . & . & + & . & + & . & . & . & . & . & . & . \\
\hline+ & . & . & + & + & + & . & . & 1 & + & · & $\cdot$ & $\cdot$ & $\cdot$ & $\cdot$ \\
\hline+ & . & + & + & . & + & . & + & + & . & . & . & . & . & . \\
\hline+ & + & + & . & + & + & + & + & . & + & . & . & . & . & . \\
\hline+ & . & . & + & + & + & . & . & + & + & . & . & . & . & . \\
\hline+ & . & + & + & + & + & . & + & + & + & . & . & . & . & . \\
\hline+ & + & + & . & . & + & + & + & . & . & . & . & . & . & . \\
\hline+ & . & . & + & + & + & . & . & + & + & . & . & . & . & . \\
\hline+ & . & + & . & . & + & . & + & . & . & . & . & . & . & . \\
\hline+ & . & + & + & + & + & . & + & + & + & $\cdot$ & $\cdot$ & $\cdot$ & $\cdot$ & $\cdot$ \\
\hline+ & + & + & . & + & + & + & + & . & + & . & . & . & . & . \\
\hline+ & + & . & + & . & + & + & . & + & . & . & . & . & . & . \\
\hline+ & + & + & . & + & + & + & + & . & + & . & . & . & . & . \\
\hline+ & + & + & + & . & + & + & + & + & . & . & . & . & . & . \\
\hline+ & + & + & . & . & + & + & + & . & . & $\cdot$ & $\cdot$ & $\cdot$ & $\cdot$ & $\cdot$ \\
\hline+ & + & + & + & + & + & + & + & + & + & . & . & . & . & . \\
\hline+ & + & . & + & . & + & + & . & + & . & . & . & . & . & . \\
\hline+ & + & + & . & . & + & + & + & . & . & . & . & . & . & . \\
\hline+ & + & . & + & + & + & + & . & + & + & . & . & . & . & $\cdot$ \\
\hline+ & . & + & + & + & + & . & + & + & + & . & . & . & . & . \\
\hline+ & + & + & . & . & + & + & + & . & . & . & . & . & . & . \\
\hline+ & . & . & . & + & + & . & . & . & + & . & . & . & $\cdot$ & · \\
\hline+ & + & + & . & . & + & + & + & . & . & . & . & . & . & . \\
\hline+ & . & + & + & . & + & . & + & + & . & . & . & . & $\cdot$ & . \\
\hline+ & + & . & + & . & + & + & . & + & . & . & . & . & . & $\cdot$ \\
\hline+ & + & . & . & . & . & + & . & . & . & . & . & . & . & $\cdot$ \\
\hline . & + & + & + & + & . & + & + & + & + & . & . & . & $\cdot$ & $\cdot$ \\
\hline . & + & + & . & . & . & + & + & . & . & . & . & . & . & . \\
\hline . & + & + & $\cdot$ & + & . & + & + & . & + & . & . & . & $\cdot$ & • \\
\hline . & . & + & + & + & . & . & + & + & + & . & . & . & . & . \\
\hline
\end{tabular}


Oxytropis halleri subsp. korabensis **

Phleum alpinum

Ranunculus breyninus

Grasslands (Dryas gr.)

belonging to the Strictly

Protected Area

Dryas octopetala

Carex kitaibeliana

Helianthemum canum

Juniperus communis subsp.

nana

Oxytropis halleri subsp.

korabensis **

Sesleria nitida

Arctostaphylos uva-ursi

Onobrychis montana subsp.

scardica **

Festuca pancicana

Festuca adamovicii **

Alchemilla plicatula

Antennaria dioica

Dianthus integer **

Bupleurum karglii **

Koeleria splendens

Bistorta vivipara

Sesleria juncifolia

Poa molinierii

Scabiosa columbaria

Phleum montanum

Erysimum comatum

Carduus candicans

Pimpinella saxifraga

Hypericum richeri subsp.

grisebachii

Silene saxifraga 
Alchemilla hybrida Achillea ageratifolia ** Geum montanum

Hieracium naegelianum subsp. ljubotenicum ** Galium anisophyllon Trifolium repens

Asperula cynanchica

Helianthemum nummularium

Campanula rotundifolia

Bromopsis cappadocica subsp. cappadocica

Anthyllis aurea **

Minuartia verna

Oxytropis campestris

Trifolium badium

Salix caprea

Dianthus sylvestris subsp.

bertisceus **

Thymus praecox subsp. zygiformis

Cerastium cerastoides

Eadrianthus graminifolius

Oenanthe peucedanifolia

Fragaria vesca

Pinus peuce

Arabis alpina

Jasione orbiculata

Dianthus scardicus **

Saxifraga scardica **

Hieracium villosum

Rubus idaeus

Trifolium noricum

Primula veris

Euphrasia rostkoviana

Cerastium decalvans 
Primula elatior

Gymnadenia nigra

Salix reticulata

Aster alpinus

Koeleria eriostachya

Achillea abrotanoides *

Trinia glauca

Veronica chamaedrys

Vaccinium uliginosum

Hypericum perforatum

Myosotis sylvatica

Stachys alpina

Luzula campestris

Lotus corniculatus

Rumex acetosa

Crepis aurea

Luzula spicata

Pedicularis brachyodonta **

Saxifraga moschata

Hieracium pilosum

Gentiana utriculosa

Bupleurum falcatum

Gentianella bulgarica

Achillea chrysocoma

Vaccinium myrtillus

Achillea setacea

Phleum alpinum

Silene ciliata

Neotinea maculata

Anthyllis vulneraria

Pinguicula balcanica **

Linum capitatum

Saxifraga paniculata

Campanula spatulata ** 
Luzula forsteri

Phyteuma pseudorbiculare **

Leontodon crispus

Ranunculus breyninus

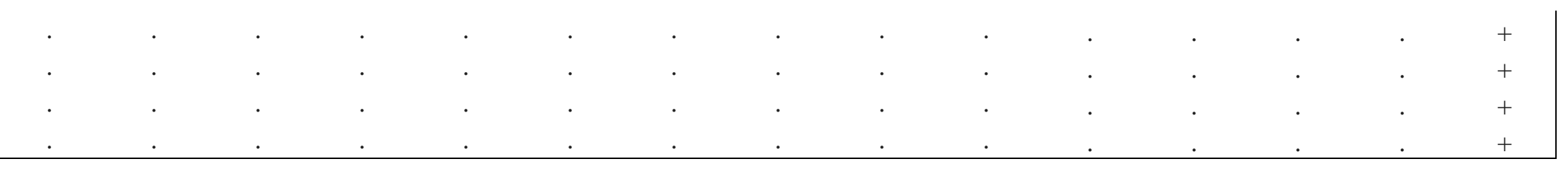

